\title{
Characterization of Argentine honeys on the basis of their mineral content and some typical quality parameters
}

\author{
Marcelo Enrique Conti ${ }^{*}$, Maria Grazia Finoia ${ }^{2}$, Luca Fontana ${ }^{3}$, Giustino Mele ${ }^{1}$, Francesco Botrè ${ }^{4}$ and Ivo lavicoli ${ }^{3}$
}

\begin{abstract}
Background: The levels of 19 elements (As, Be, Ca, Cd, Co, Cr, Cu, Fe, K, Mg, Mn, Na, Ni, Pb, Se, Tl, U, V, Zn) from sixteen different Argentine production sites of unifloral [eucalyptus (Eucaliptus rostrata), chilca (Baccharis salicifolia), Algarrobo (Prosopis sp.), mistol (Ziziphus mistol) and citric] and multifloral honeys were measured with the aim to test the quality of the selected samples. Typical quality parameters of honeys were also determined $(\mathrm{pH}$, sugar content, moisture). Mineral elements were determined by using inductively coupled plasma mass spectrometer (ICP-MS DRC). We also evaluated the suitability of honey as a possible biomonitor of environmental pollution. Thus, the sites were classified through cluster analysis (CA) and then pattern recognition methods such as Principal Component Analysis (PCA) and discriminant analysis (DA) were applied.

Results: Mean values for quality parameters were: $\mathrm{pH}, 4.12$ and 3.81; sugar 82.1 and 82.0 'brix; moisture, 16.90 and $17.00 \%$ for unifloral and multifloral honeys respectively. The water content showed good maturity. Likewise, the other parameters confirmed the good quality of the honeys analysed. Potassium was quantitatively the most abundant metal, accounting for $92,5 \%$ of the total metal contents with an average concentration of 832.0 and $816.2 \mu \mathrm{g} \mathrm{g}^{-1}$ for unifloral and multifloral honeys respectively. Sodium was the second most abundant major metal in honeys with a mean value of 32.16 and $33.19 \mathrm{\mu g} \mathrm{g}^{-1}$ for unifloral and multifloral honeys respectively. $\mathrm{Mg}, \mathrm{Ca}, \mathrm{Fe}, \mathrm{Mn}, \mathrm{Zn}$ and $\mathrm{Cu}$ were present at low-intermediate concentrations. For the other 11 trace elements determined in this study $(\mathrm{As}, \mathrm{Be}, \mathrm{Cd}, \mathrm{Co}$, $\mathrm{Cr}, \mathrm{Ni}, \mathrm{Pb}, \mathrm{Se}, \mathrm{Tl}, \mathrm{U}$ and $\mathrm{V}$, the mean concentrations were very low or below of the LODs. The sites were classified through CA by using elements' and physicochemical parameters data, then DA on the PCA factors was applied. Dendrograms identified three main groups. PCA explained $52.03 \%$ of the total variability with the first two factors.

Conclusions: In general, there are no evidences of pollution for the analysed honeys. The analytical results obtained for the Argentine honeys indicate the products' high quality. In fact, most of the toxic elements were below LODs. The chemometric analysis combining CA, DA and PCA showed their aptness as useful tools for honey's classification. Eventually, this study confirms that the use of honey as biomonitor of environmental contamination is not reliable for sites with low levels of contamination.
\end{abstract}

Keywords: Honey, Elements' content, Quality parameters, Multivariate statistical tools, Cluster analysis, Pattern recognition methods, Environmental biomonitoring

\footnotetext{
* Correspondence: marcelo.conti@uniroma1.it

'Department of Management, University of Rome, Sapienza, Via del Castro

Laurenziano 9, Rome 00161, Italy

Full list of author information is available at the end of the article
}

\section{(D) Chemistry Central}

(c) 2014 Conti et al.; licensee Chemistry Central Ltd. This is an Open Access article distributed under the terms of the Creative Commons Attribution License (http://creativecommons.org/licenses/by/4.0), which permits unrestricted use, distribution, and reproduction in any medium, provided the original work is properly credited. The Creative Commons Public Domain Dedication waiver (http://creativecommons.org/publicdomain/zero/1.0/) applies to the data made available in this article, unless otherwise stated. 


\section{Background}

Honey is defined as "the natural sweet substance produced by Apis mellifera bees from the nectar of plants or from secretions of living parts of plants or excretions of plant-sucking insects on the living parts of plants, which the bees collect, transform by combining with specific substances of their own, deposit, dehydrate, store and leave in honeycombs to ripen and mature" [1]. Argentina is one of the major producers of bee honey and is the leading global exporter of high quality honey. About 50\% come from the Province of Buenos Aires [2,3]. For instance, the United States imports 19\% of their foreign honey from Argentina, spending about 54 million dollars in 2010. Also European countries such as Italy and Germany are strongly influenced by competition from Argentine and Chinese varieties whose prices are lower by roughly $50 \%$ [4].

Honey has high nutritional value $(330 \mathrm{kcal} / 100 \mathrm{~g})$ and fast absorption of its carbohydrates on consumption. It is a high carbohydrate food and shows anti-bacterial and anti-inflammatory properties in the treatment of skin wounds and several gastrointestinal diseases [4-10]. Honey activates the immune system and its ingestion may be beneficial with respect to cancer and metastasis prevention $[5,10]$. Hydrogen peroxide produced enzymatically is responsible for honey's antibacterial activity [7]. Honey is a potent inhibitor of the bacterium Helicobacter pylori that causes peptic ulcers and gastritis [10].

The European Union [1] defines general and specific compositional characteristics of honey such as sugar content, humidity, acidity, electrical conductivity, diastase activity and hydroxymethylfurfural (HMF) content. Moreover, labels on honey packaging should report information on the product's regional or topographical origin, floral or vegetable origin. If honey originates from different countries the label should specify "blend of EU (or no-EU) honeys" or "blend of EU and no-EU honeys".

The composition and properties of a particular honey sample depend highly on the type of flowers visited by the bees, as well as on the climatic conditions in which the plants grow [11,12]. Melissopalynology (pollen analysis) is the traditional method used to determine the botanical origin of honeys [13,14], but this technique has some limitations [15]. In fact, melissopalynology requires relevant knowledge of pollen morphology and specialised professional personnel to achieve reliable results [13]. However, nowadays in spite of these problems melissopalynology remains the reference method.

Bees forage an area of about $7 \mathrm{~km}^{2}$ and came in contact constantly with the surrounding environment. The chemical composition and properties of honey depend on the type of flowers visited by the bees, as well as on the climatic conditions in which the plants grow $[4,9]$. This also implies that honeybees and their products (i.e. pollen, wax, etc.) can be employed as potential biomonitors of environmental contamination $[9,16]$. Finally, the specific chemical and physical properties can be used for the determination of the botanical origin of honey $[17,18]$.

The role of elements in honey is of high relevance [19-21] in terms of both its quality and safety. Scarce information is available on the elements' composition of Argentine honeys, this is also connected with the relevance of Argentina as one of the main honey exporter in the world. In fact, only $5 \%$ of the total honey production in Argentina is destined to domestic consumption.

The aim of the work was to measure the levels of 19 elements (As, Be, $\mathrm{Ca}, \mathrm{Cd}, \mathrm{Co}, \mathrm{Cr}, \mathrm{Cu}, \mathrm{Fe}, \mathrm{K}, \mathrm{Mg}, \mathrm{Mn}$, $\mathrm{Na}, \mathrm{Ni}, \mathrm{Pb}, \mathrm{Se}, \mathrm{Tl}, \mathrm{U}, \mathrm{V}, \mathrm{Zn}$ ) and some typical quality parameters $(\mathrm{pH}$, sugar content, moisture) from sixteen different Argentine production sites of unifloral [i.e. eucalyptus, chilca (Baccharis spp.), Algarrobo (Prosopis sp.), mistol (Ziziphus mistol) and citric] and multifloral honey samples. Duplicate samples were taken from each production area. Due to its economic relevance for export purposes and for production levels, samples were mainly collected in the Province of Buenos Aires.

We have evaluated, by means of multivariate statistical methods whether the physicochemical parameters and the elements' content can classify or discriminate the sampling sites in order to confirm the suitability of honey as a possible biomonitor of environmental pollution. Thus, the sites were classified through cluster analysis by using elements' data, then pattern recognition methods such as Principal Component Analysis (PCA) and discriminant analysis (DA) were applied (see Statistical methods section for details).

\section{Results and discussion}

Table 1 reports the mean \pm SD and the range of the physicochemical parameters for the analysed honeys. Reported data for the physicochemical parameters were homogeneous for the analyzed honeys, showing very low SD levels (Table 1).

Table 1 Descriptive statistics for physicochemical parameters in Argentine honey samples

\begin{tabular}{lcccc}
\hline & N & Mean \pm SD & MIN & MAX \\
\hline SUGAR [ ${ }^{\circ}$ brix] & & & & \\
Unifloral & 5 & $82.1 \pm 0.7$ & 81.5 & 83.0 \\
Multifloral & 11 & $82.0 \pm 1.2$ & 80.5 & 84.0 \\
pH & & & & \\
Unifloral & 5 & $4.12 \pm 0.21$ & 3.87 & 4.46 \\
Multifloral & 11 & $3.81 \pm 0.27$ & 3.55 & 4.43 \\
MOISTURE [\%] & & & & \\
Unifloral & 5 & $16.9 \pm 0.6$ & 16.0 & 17.5 \\
Multifloral & 11 & $17.0 \pm 1.3$ & 15.0 & 19.0 \\
\hline
\end{tabular}


The $\mathrm{pH}$ ranged between 3.87 and 4.46 with a mean value of 4.12 for unifloral honeys, while the range was between 3.55 and 4.43 with a mean of 3.81 for multifloral honeys.

Most bacteria and moulds grow in a neutral and mildly alkaline environment respectively, while yeasts require an acidic environment $(\mathrm{pH}=4.0-4.5)$ and do not grow in alkaline media [22]. In fact, $\mathrm{pH}$ is a useful index of possible microbial contamination [23] and has great relevance during the extraction and storage of honey because it is connected with the texture and the product's shelf life [24].

The mean $\mathrm{pH}$ value (3.81) of multifloral Argentine honeys was similar than those reported by Baroni et al. [25] for Córdoba (Argentina) honeys and by Conti et al. [4] for Italian honeys (Marche Region); while the obtained mean $\mathrm{pH}$ value for unifloral honeys (i.e. 4.12) was comparable to those of Lazio Region (Italy) honeys [24] and to Andalusian (Spain) unifloral honeys [26].

Water content is connected with the climatic conditions and the degree of maturity; anomalous values may be an index of adulterations. It generally depends on the botanical origin of the sample, the processing techniques and the storage conditions [4,24,27]. Mean humidity was $17.0 \%$ with a range of between 15.0 - $19.0 \%$ for multifloral honeys and a mean of $16.9 \%$ with a range of between $16.0-17.5 \%$ for unifloral honeys. None of the samples exceeded the limit permitted of $20 \%$ by the Codex Alimentarius [28] and the Council Directive [1]. However one sample (code M8, Entre Rios Province) showed a value higher than the limit of $18 \%$ established by the Argentine legislation [29]. Our results generally confirm that the fermentation rate is very low in the analyzed samples. Moisture values observed for our samples were slightly lower than those obtained for Córdoba (Argentina) honeys [25] and quite similar to honeys from Buenos Aires Region [30], and to those of Andalusia (Spain) [26], Lazio Region (Italy) [24], Serbian Acacia honeys [27] and to Entre-Douro e Minho Region of Portugal [31].

The average total sugar content was $82.1 \%$ and the range was 81.5 - 83.0\% for unifloral honeys, and a mean of $82.0 \%$ with a range of between $80.5-84.0 \%$ for multifloral honeys. Our results match those obtained for Italian and Spanish honeys $[4,23,24,26]$.

Tables 2 and 3 show the mean, standard deviation and the concentration ranges of the elements for unifloral and multifloral honey samples respectively.

Potassium was quantitatively the most abundant metal, accounting for $92,5 \%$ of the total metal contents with an average concentration of 832.0 and $816.2 \mu \mathrm{g} \mathrm{g}^{-1}$ (wet weight) for unifloral and multifloral Argentine honeys respectively. For data comparison, the results were appropriately transformed (i.e. wet or dry basis) when necessary.
As above pointed out, little information is available on mineral content in Argentine honeys. Our mean potassium levels were considerably higher than those of Córdoba (Argentina) honeys [25] and to Lazio (Italy) honeys [24] and higher to Marche region honeys (Italy) [4]. This result is consistent with other reported data $[9,19,32]$.

Sodium, as expected, was the second most abundant major metal in honeys. We determined a mean sodium content of 32.16 and $33.19 \mu \mathrm{g} \mathrm{g}^{-1}$ (w.w.) for unifloral and multifloral Argentine honeys respectively. Mean sodium values were lower than Córdoba (Argentina) honeys [25] and Lazio (Italy) honeys [24]; while we obtained slightly higher mean values than those reported for Marche region (Italy) honeys [4].

Mean magnesium levels were 17.26 and 22.64 $\mu \mathrm{g} \mathrm{g}^{-1} \mathrm{w} . \mathrm{w}$. in unifloral and multifloral Argentine honeys respectively, and were quite higher than those determined in Córdoba (Argentina) honeys [25]. Calcium mean levels, i.e. 6.92 and $10.86 \mu \mathrm{g} \mathrm{g}^{-1}$ w.w, for unifloral and multifloral Argentine honeys respectively, were lower than Córdoba (Argentina) honeys [25], than to Spanish [33], and to Lazio and Marche Regions (Italy) honeys [4,24]. The mean iron levels in our samples, 3.57 and $2.99 \mu \mathrm{g} \mathrm{g}^{-1}$ w.w. for unifloral and multifloral Argentine honeys respectively, were lower than those of Córdoba (Argentina) [25], to San Luis - La Pampa honeys (middle Argentina) [34] and to Lazio and Marche Regions (Italy) honeys [4,24].

The mean manganese levels (2.61 and $1.05 \mu \mathrm{g} \mathrm{g}^{-1}$ w.w.) were higher to those found for Córdoba (Argentina) honeys [25], and to Marche region (Italy) honeys [4], and lower than Lazio region (Italy) honeys [24]. The mean zinc levels (0.87 and $1.17 \mu \mathrm{g} \mathrm{g}^{-1}$ w.w.) were lower than those found for Córdoba (Argentina) honeys [25] and Lazio honeys [24] and comparable to those found for San Luis - La Pampa honeys (middle Argentina) [34].The mean copper levels for our samples (0.18 and $0.29 \mu \mathrm{g} \mathrm{g}^{-1}$ ) are lower than those of Lazio honeys [24] while $\mathrm{Cu}$ was not detected in the Còrdoba (Argentina) honeys [25].

Potassium showed positive correlation with $\mathrm{Ca}[\mathrm{r}=0.70 \mathrm{t}$ $(14)=3.68 \mathrm{p}=0.002], \mathrm{Mg}[\mathrm{r}=0.76 \mathrm{t}(14)=4.44 \mathrm{p}<0.001]$ and $\mathrm{Cu}[\mathrm{r}=0.73 \mathrm{t}(14)=4.04 \mathrm{p}=0.001]$. Calcium correlated positively with $\mathrm{Mg}[\mathrm{r}=0.77 \mathrm{t}(14)=4.53 \mathrm{p}<0.001]$ and $\mathrm{Cu}[\mathrm{r}=0.50 \mathrm{t}(14)=2.17 \mathrm{p}=0.047]$. Sodium correlated positively with $\mathrm{Ca}[\mathrm{r}=0.524 \mathrm{t}(14)=2.30 \mathrm{p}=0.037]$.

The presence of these major essential elements in honey such as $\mathrm{Ca}, \mathrm{K}, \mathrm{Na}$ and $\mathrm{Mg}$ is of certain nutritional relevance and dietary value, mainly connected with children's health $[9,19]$. As previously reported [24] the intake of many major and minor metals (i.e. Fe, $\mathrm{Mn}, \mathrm{Cu}$ and $\mathrm{Zn}$ ) from honey is very low due to its low level of consumption. Generally, honey does not contribute for a significant proportion of minerals recommended dietary allowances (RDAs), usually from a few per cent, or even lower $[24,35]$. 
Table 2 Descriptive statistics of elements' content ( $\mu \mathrm{g} \mathrm{g}^{-1}$ wet weight) in Argentine unifloral honey samples

\begin{tabular}{|c|c|c|c|c|c|c|c|c|}
\hline & $\begin{array}{l}\text { Eucalipto (EntreRios) } \\
\text { M1 }\end{array}$ & $\begin{array}{c}\text { Chilca (Còrdoba) } \\
\text { M2 }\end{array}$ & $\begin{array}{c}\text { Algarrobo (S. del Estero) } \\
\text { M3 }\end{array}$ & $\begin{array}{c}\text { Mistol (S. del Estero) } \\
\text { M4 }\end{array}$ & $\begin{array}{c}\text { Citric (Tucumàn) } \\
\text { M5 }\end{array}$ & Mean \pm SD & Min & Max \\
\hline As & $<0.01$ & $<0.01$ & $<0.01$ & $<0.01$ & $<0.01$ & - & $<0.01$ & $<0.01$ \\
\hline $\mathrm{Be}$ & $<0.01$ & $<0.01$ & $<0.01$ & $<0.01$ & $<0.01$ & - & $<0.01$ & $<0.01$ \\
\hline $\mathrm{Ca}$ & 6.18 & 2.50 & 4.13 & 13.74 & 8.04 & $6.92 \pm 4.35$ & 2.50 & 13.74 \\
\hline $\mathrm{Cd}$ & $<0.01$ & $<0.01$ & $<0.01$ & 0.01 & $<0.01$ & $0.01 \pm 0.00$ & $<0.01$ & 0.01 \\
\hline Co & 0.01 & $<0.01$ & $<0.01$ & $<0.01$ & $<0.01$ & $0.01 \pm 0.00$ & $<0.01$ & 0.01 \\
\hline $\mathrm{Cr}$ & $<0.01$ & $<0.01$ & $<0.01$ & $<0.01$ & $<0.01$ & - & $<0.01$ & $<0.01$ \\
\hline $\mathrm{Cu}$ & 0.27 & 0.12 & 0.20 & 0.18 & 0.15 & $0.18 \pm 0.06$ & 0.12 & 0.27 \\
\hline $\mathrm{Fe}$ & 3.38 & 2.19 & 4.05 & 3.73 & 4.50 & $3.57 \pm 0.87$ & 2.19 & 4.50 \\
\hline $\mathrm{K}$ & 488.4 & 251.1 & 318.4 & 2022.6 & 1079.8 & $832.0 \pm 741.3$ & 251.1 & 2022.6 \\
\hline $\mathrm{Mg}$ & 14.37 & 4.59 & 8.12 & 37.98 & 21.26 & $17.26 \pm 13.21$ & 4.59 & 37.98 \\
\hline $\mathrm{Mn}$ & 8.84 & 0.77 & 1.14 & 1.60 & 0.70 & $2.61 \pm 3.50$ & 0.70 & 8.84 \\
\hline $\mathrm{Na}$ & 62.00 & 7.21 & 39.27 & 34.65 & 17.67 & $32.16 \pm 21.09$ & 7.21 & 62.00 \\
\hline $\mathrm{Ni}$ & 0.05 & 0.01 & 0.06 & 0.02 & 0.03 & $0.04 \pm 0.02$ & 0.01 & 0.06 \\
\hline $\mathrm{Pb}$ & 0.01 & 0.02 & 0.02 & 0.01 & 0.02 & $0.02 \pm 0.01$ & 0.01 & 0.02 \\
\hline Se & 0.01 & $<0.01$ & $<0.01$ & 0.01 & $<0.01$ & $0.01 \pm 0.00$ & 0.01 & 0.01 \\
\hline $\mathrm{TI}$ & $<0.01$ & $<0.01$ & $<0.01$ & $<0.01$ & $<0.01$ & - & $<0.01$ & $<0.01$ \\
\hline $\mathbf{U}$ & $<0.01$ & $<0.01$ & $<0.01$ & $<0.01$ & $<0.01$ & - & $<0.01$ & $<0.01$ \\
\hline $\mathbf{v}$ & $<0.01$ & $<0.01$ & $<0.01$ & $<0.01$ & $<0.01$ & - & $<0.01$ & $<0.01$ \\
\hline $\mathrm{Zn}$ & 0.55 & 1.05 & 1.42 & 0.84 & 0.51 & $0.87 \pm 0.38$ & 0.51 & 1.42 \\
\hline
\end{tabular}

For the other 11 trace elements determined in this study (As, Be, Cd, Co, Cr, Ni, Pb, Se, Tl, U and V), the mean concentrations were very low or below of the LODs (Tables 2 and 3). In general, the presence of these elements can indicate contamination during honey processing, shipping or storage connected with the use of steel or galvanized containers [19]. However, in an another study chromium levels in some honey samples collected in the Buenos Aires province (Argentina) were in the range of $0.9-6 \mu \mathrm{g} \mathrm{g}^{-1}$ [36] while a mean concentration of $0.47 \mu \mathrm{g} \mathrm{g}^{-1}$ is reported for San Luis - La Pampa honeys (middle Argentina) [34].

Lead levels were lower than others obtained for honeys collected in the Buenos Aires province (Argentina) [36], and comparable to those reported for Turkish honeys [37], while our nickel levels were higher than those of Turkish honeys [37]. Generally, with rare exceptions, our data for some trace elements (i.e. As, $\mathrm{Cd}, \mathrm{Co}, \mathrm{Cr}, \mathrm{Pb}$ ) are comparable or at a lower levels than those reported for other countries [38-42]. Very scarce information is present in literature about some elements in Argentine honeys such us $\mathrm{Ni}, \mathrm{Se}, \mathrm{Tl}, \mathrm{U}$ and $\mathrm{V}$. Our selenium levels were lower than those measured in Turkish honeys [37]. While we not detected uranium and vanadium in our samples (LOD $<0.01 \mu \mathrm{g} \mathrm{g}^{-1}$, Tables 2 and 3) Almeida-Silva et al. [43] reported levels of 0.34 and $0.28 \mu \mathrm{g} \mathrm{g}^{-1}$ of $\mathrm{U}$ and 13.5 and $5.6 \mu \mathrm{g} \mathrm{g}^{-1}$ of vanadium in Portuguese honeys.
We have no found data for beryllium in honeys in the literature. However, we detected Be only in the Entre Ríos (M8) multifloral sample $\left(0.10 \mu \mathrm{g} \mathrm{g}^{-1}\right)$ while the others were below LODs. At present, there are no studies that suggested a health risk for the presence of beryllium in food and drinking water, even if it can be an index of industrial contamination [44].

Overall, from our results we can infer that there are no evidences of pollution for the analysed honeys and these results confirm their good quality.

We applied the hierarchical clustering by using data set (Tables 1, 2 and 3, see also Experimental section below) in order to classify the production sites. The result of the cluster analysis is reported in Figure 1. The $\mathrm{x}$ axis depicts the sampling sites while the $y$ axis indicates the calculated distances among sampling sites. From Figure 1 we observe that there are three main groups. The honeys produced in the provinces of Córdoba and Tucumán are grouped in the A cluster. The honeys produced in the provinces of Entre Ríos and Santiago (i.e. Santiago del Estero) are grouped in the B cluster, and those produced in the Buenos Aires province are linked with the A cluster at the last step of the iterative aggregation process.

Thus, in order to discriminate the elements and parameters classified by cluster analysis, we applied discriminant analysis (DA) on principal component analysis (PCA) factors (see experimental section). PCA explained 52.03\% 
Table 3 Descriptive statistics of elements' content ( $\mu \mathrm{g} \mathrm{g}^{-1}$ wet weight) in Argentine multifloral honey samples

\begin{tabular}{|c|c|c|c|c|c|c|c|c|c|c|c|c|c|c|}
\hline & Còrdoba & $\begin{array}{l}\text { Prov. Buenos } \\
\text { Aires }\end{array}$ & $\begin{array}{l}\text { Entre } \\
\text { Rios }\end{array}$ & $\begin{array}{l}\text { Entre } \\
\text { Rios }\end{array}$ & $\begin{array}{l}\text { Prov. Buenos } \\
\text { Aires }\end{array}$ & $\begin{array}{l}\text { Prov. Buenos } \\
\text { Aires }\end{array}$ & $\begin{array}{l}\text { Prov. Buenos } \\
\text { Aires }\end{array}$ & $\begin{array}{l}\text { Prov. Buenos } \\
\text { Aires }\end{array}$ & $\begin{array}{l}\text { Prov. Buenos } \\
\text { Aires }\end{array}$ & $\begin{array}{l}\text { Prov. Buenos } \\
\text { Aires }\end{array}$ & $\begin{array}{l}\text { Prov. Buenos } \\
\text { Aires }\end{array}$ & Mean \pm SD & Min & Max \\
\hline & M6 & M7 & M8 & M9 & M10 & M11 & M12 & M13 & M14 & M15 & M16 & & & \\
\hline As & $<0.01$ & $<0.01$ & $<0.01$ & 0.01 & $<0.01$ & $<0.01$ & $<0.01$ & $<0.01$ & $<0.01$ & $<0.01$ & $<0.01$ & $0.01 \pm 0.00$ & $<0.01$ & 0.01 \\
\hline $\mathrm{Be}$ & $<0.01$ & $<0.01$ & 0.10 & $<0.01$ & $<0.01$ & $<0.01$ & $<0.01$ & $<0.01$ & $<0.01$ & $<0.01$ & $<0.01$ & $0.10 \pm 0.00$ & $<0.01$ & 0.10 \\
\hline $\mathrm{Ca}$ & 7.57 & 6.03 & 17.26 & 18.97 & 15.33 & 14.68 & 13.61 & 18.61 & 2.93 & 1.97 & 2.50 & $10.86 \pm 6.75$ & 1.97 & 18.97 \\
\hline $\mathrm{Cd}$ & $<0.01$ & $<0.01$ & $<0.01$ & 0.03 & 0.01 & 0.01 & $<0.01$ & $<0.01$ & $<0.01$ & $<0.01$ & $<0.01$ & $0.02 \pm 0.01$ & $<0.01$ & 0.03 \\
\hline Co & $<0.01$ & $<0.01$ & 0.01 & 0.01 & $<0.01$ & 0.01 & $<0.01$ & $<0.01$ & $<0.01$ & 0.01 & $<0.01$ & $0.01 \pm 0.00$ & $<0.01$ & 0.01 \\
\hline $\mathrm{Cr}$ & $<0.01$ & 0.01 & 0.01 & $<0.01$ & $<0.01$ & $<0.01$ & 0.05 & 0.04 & $<0.01$ & $<0.01$ & $<0.01$ & $0.03 \pm 0.02$ & $<0.01$ & 0.05 \\
\hline $\mathrm{Cu}$ & 0.13 & 0.09 & 0.38 & 1.19 & 0.17 & 0.20 & 0.12 & 0.32 & 0.20 & 0.17 & 0.21 & $0.29 \pm 0.31$ & 0.09 & 1.19 \\
\hline $\mathrm{Fe}$ & 4.40 & 2.07 & 3.15 & 2.24 & 2.32 & 4.18 & 2.26 & 3.99 & 2.40 & 3.22 & 2.68 & $2.99 \pm 0.86$ & 2.07 & 4.40 \\
\hline $\mathrm{K}$ & 1225.8 & 324.9 & 1408.2 & 2813.3 & 755.8 & 476.2 & 412.3 & 1107.5 & 176.6 & 134.1 & 143.9 & $816.2 \pm 802.6$ & 134.1 & 2813.3 \\
\hline Mg & 18.12 & 12.39 & 75.38 & 49.77 & 19.68 & 23.57 & 16.46 & 23.87 & 3.43 & 3.01 & 3.31 & $22.64 \pm 21.95$ & 3.01 & 75.38 \\
\hline Mn & 0.57 & 0.55 & 2.39 & 3.13 & 1.18 & 0.57 & 0.14 & 0.40 & 0.60 & 1.40 & 0.59 & $1.05 \pm 0.93$ & 0.14 & 3.13 \\
\hline $\mathrm{Na}$ & 20.05 & 4.88 & 36.30 & 28.62 & 105.95 & 25.19 & 25.79 & 76.44 & 13.26 & 15.45 & 13.16 & $33.19 \pm 30.66$ & 4.88 & 105.95 \\
\hline $\mathrm{Ni}$ & 0.02 & 0.02 & 0.07 & 0.05 & 0.02 & 0.05 & 0.03 & 0.04 & 0.03 & 0.05 & 0.02 & $0.04 \pm 0.02$ & 0.02 & 0.07 \\
\hline $\mathrm{Pb}$ & 0.01 & 0.04 & 0.01 & 0.01 & 0.04 & 0.04 & 0.01 & 0.04 & 0.01 & 0.03 & 0.01 & $0.02 \pm 0.02$ & 0.01 & 0.04 \\
\hline Se & $<0.01$ & $<0.01$ & $<0.01$ & $<0.01$ & $<0.01$ & $<0.01$ & $<0.01$ & $<0.01$ & $<0.01$ & $<0.01$ & $<0.01$ & - & $<0.01$ & $<0.01$ \\
\hline TI & $<0.01$ & $<0.01$ & $<0.01$ & $<0.01$ & $<0.01$ & $<0.01$ & $<0.01$ & $<0.01$ & $<0.01$ & $<0.01$ & $<0.01$ & - & $<0.01$ & $<0.01$ \\
\hline $\mathrm{U}$ & $<0.01$ & $<0.01$ & $<0.01$ & $<0.01$ & $<0.01$ & $<0.01$ & $<0.01$ & $<0.01$ & $<0.01$ & $<0.01$ & $<0.01$ & - & $<0.01$ & $<0.01$ \\
\hline $\mathrm{v}$ & $<0.01$ & $<0.01$ & $<0.01$ & $<0.01$ & $<0.01$ & $<0.01$ & $<0.01$ & $<0.01$ & $<0.01$ & $<0.01$ & $<0.01$ & - & $<0.01$ & $<0.01$ \\
\hline $\mathrm{Zn}$ & 2.75 & 1.22 & 0.80 & 0.70 & 0.81 & 2.04 & 1.50 & 0.74 & 0.72 & 0.92 & 0.70 & $1.17 \pm 0.67$ & 0.70 & 2.75 \\
\hline
\end{tabular}




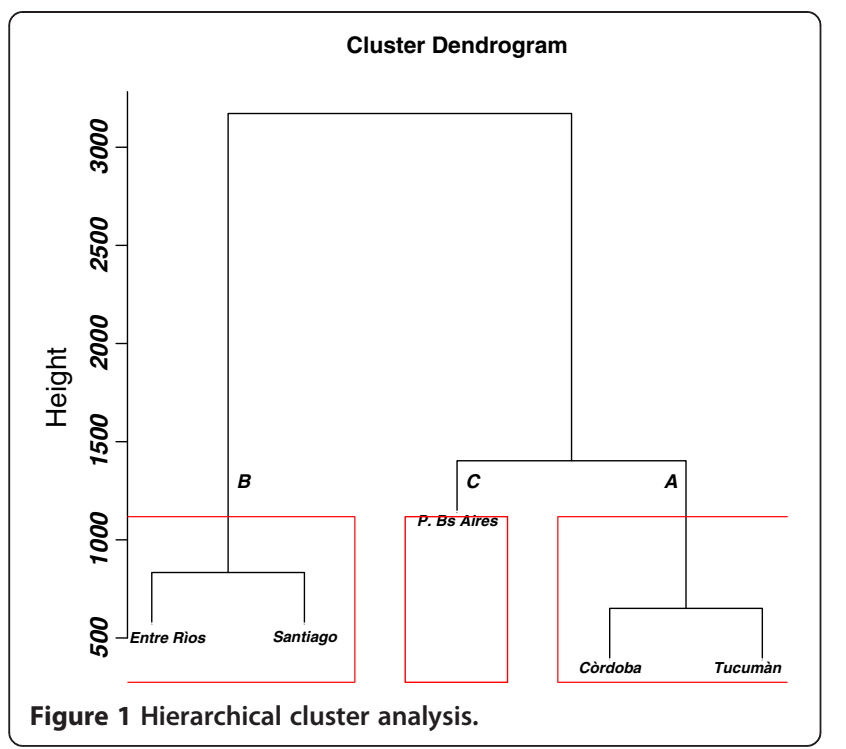

of the total variability with the first two factors. Elements such as As, Be, Cd, Co, Cr, Se, Tl, U, V had to be eliminated from the data set because of their too low levels (or below LODs). Therefore, the data matrix was constituted by thirteen loadings: $\mathrm{Ca}, \mathrm{Cu}, \mathrm{Fe}, \mathrm{K}, \mathrm{Mg}, \mathrm{Mn}, \mathrm{Na}, \mathrm{Ni}, \mathrm{Pb}$, $\mathrm{Zn}$, moisture, sugar content and $\mathrm{pH}$. Results are reported in Figure 2.

From this study we can draw some findings. First, the cluster A (honeys from Córdoba and Tucumán provinces) has higher concentrations of $\mathrm{Zn}$ and $\mathrm{Fe}$ and lower concentrations of $\mathrm{Ca}, \mathrm{Na}$ and $\mathrm{Ni}$ compared to the other groups. Second, the cluster B (Entre Ríos and Santiago honeys) is characterized by higher concentrations of $\mathrm{K}, \mathrm{Mg}, \mathrm{Mn}, \mathrm{Cu}$ and $\mathrm{Ni}$ and higher $\mathrm{pH}$ levels than the other clusters. Moreover, the honeys of the cluster B have lower levels of Zn than the others. Third, the cluster $C$ (Buenos Aires province honeys) showed higher levels of $\mathrm{Pb}$ than the other groups and lower levels of sugar, $\mathrm{pH}$ and $\mathrm{K}, \mathrm{Mg}, \mathrm{Mn}$ and Fe.

However, these results can be considered as indicative because the DA did not result significant (Montecarlo test $\mathrm{RV}=0.126 \mathrm{p}=0.754)$. Thus, the elements and physiological parameters determined in honey have weak discriminating power. This is of relevance because it further confirms our previous statements [16] that honey is not a reliable biomonitor of environmental contamination, in particular in sites with low levels of contamination (see also refs. [9,45] for discussion). Furthermore, we also conducted the DA on the PCA factors considering the variables 'unifloral' and 'multifloral' honeys for the elements and physiological parameters determined (results not shown), but also in this case DA resulted not significant (Montecarlo test $R V=0.073$ $\mathrm{p}=0.309$ ). This further agrees with the statements above reported.

\section{Conclusions}

In general, we can infer that there are no evidences of pollution for the analysed honeys. The analytical results obtained for the Argentine honeys indicate the products' high quality. In fact, most of the toxic elements were below LODs. The chemometric analysis combining CA, DA and PCA showed their aptness as useful tools for honey's classification. This study further confirms that the use of honey as biomonitor of environmental contamination is not reliable for sites with low levels of contamination.

Eventually, further research is needed in order to characterize Argentine honeys by means of pattern recognition methods of zones with high production levels and in order to improve their economic interest.

\section{Experimental}

\section{Samples}

The study was conducted on 16 samples of the typical honeys coming from different production areas in Argentina. Five unifloral and eleven multifloral samples were collected and analysed in duplicate (see Table 4 for description). All collected samples were taken from the local beekeepers' association with a guarantee of genuineness. All samples were collected, stored in plastic holders and kept at $4-5^{\circ} \mathrm{C}$ until analysis.

\section{$\mathrm{pH}$, sugar content and moisture}

The $\mathrm{pH}$ was assessed by means of a potentiometer utilizing a pH meter Mettler Delta 345 (Mettler Toledo, Milano, Italy) [46]. Sugar and moisture values were determined utilizing a Bertuzzi refractometer (Bertuzzi, Milano, Italy) owing two direct reading displays, for the measurement of sugar content and moisture percent respectively (Chatway method). Total sugar content was expressed as brix degrees [46].

\section{Determination of mineral elements}

About $0.8 \mathrm{~g}$ of fresh honey was treated with $3.5 \mathrm{ml}$ of $70 \%(\mathrm{w} / \mathrm{w})$ Nitric Acid Suprapur (Merck, Suprapur, Darmstadt, Germany) and $1.5 \mathrm{ml}$ of $30 \%(\mathrm{w} / \mathrm{w})$ Hydrogen Peroxide Suprapur (Merck, Darmstadt, Germany) in PTFE vessels. The microwave closed digestion system (Milestone, Start D) was used for the mineralization process. The treatment procedure was programmed in four steps with a power of $1200 \mathrm{~W}$ applied for 5, 3, 8 and $15 \mathrm{~min}$ each respectively. The temperature was $120^{\circ} \mathrm{C}$ for the first two steps and $200^{\circ} \mathrm{C}$ for the second two steps. A sample of reference materials and blank was included in each analytical batch. Subsequently, digestion vessels were cooled to room temperature. The final clear solution was made up to $15 \mathrm{~mL}$ with DWI water. Digestion methods in biological and environmental matrices were discussed in our previous studies $[47,48]$. 


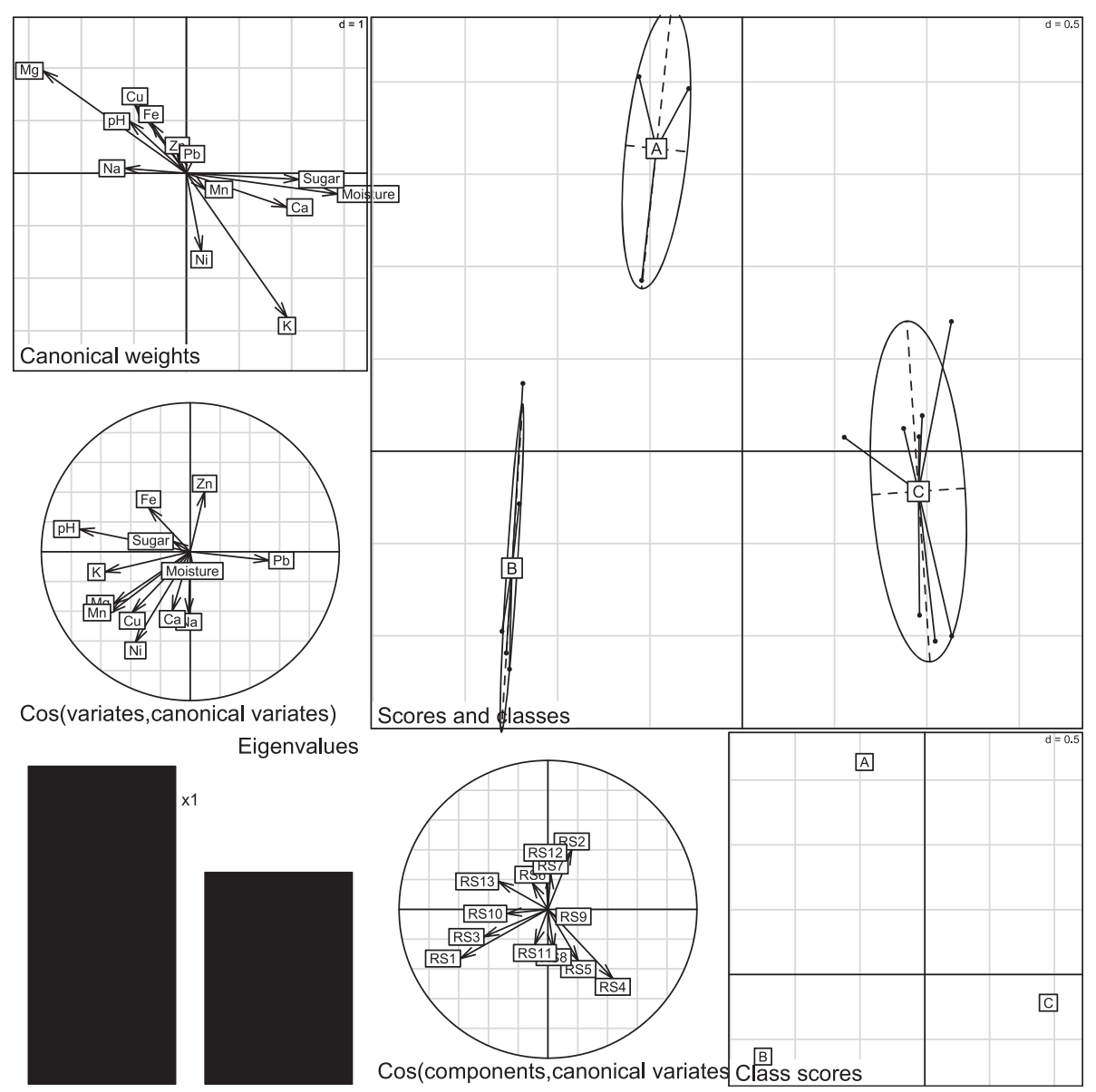

Figure 2 DA on PCA factors for honeys' elements data and physicochemical parameters applied for the Hierarchical Cluster Analysis results. Composed plot; (top left): the plot of the canonical weights; (middle left) the plot of canonical correlations between variates and the first two canonical discriminant functions; (bottom left): the eigenvalues bar chart; (bottom centre): the plot of PCA factors into LDA plane; (bottom right): the gravity centers of classes; [main graph]: the projection of the canonical scores with ellipses and gravity center of classes.

The samples were quantified for 19 elements: As, Be, $\mathrm{Ca}, \mathrm{Cd}, \mathrm{Co}, \mathrm{Cr}, \mathrm{Cu}, \mathrm{Fe}, \mathrm{K}, \mathrm{Mg}, \mathrm{Mn}, \mathrm{Na}, \mathrm{Ni}, \mathrm{Pb}, \mathrm{Se}, \mathrm{Tl}, \mathrm{U}$, $\mathrm{V}$ and $\mathrm{Zn}$, in digested honeys by inductively coupled plasma mass spectrometry [ICP-MSDRC-e (Dynamic Reaction Cell) mod. Elan, Perkin Elmer]. Traceability of results was obtained from the analysis of the certified reference materials NIST-1515 (Apple leaves - National Institute of Standards and Technology) and the Antartic Krill MURST-ISS-A2 (Italian Research Programme in Antarctica). For the MURST-ISS-A2 the mean recovery percentages (five replicates) were: As: $94.1 \pm 2.8 \%$; Cd: $93.6 \pm 2.8 \%$; Co: $101.2 \pm 1.8 \%$; Cr: $98.0 \pm 1.1 \%$ (not certified, informative concentration); $\mathrm{Cu}: 101.4 \pm 2.0 \%$; Ni: $97.9 \pm$ 2.4\%; Pb: $97.0 \pm 0.9 \%$; Se: $96.8 \pm 2.9 \%$ and $\mathrm{Zn}: 102.1 \pm 2.8 \%$. For the NIST-1515 the mean recovery percentages (five replicates) were: $\mathrm{Ca}$ : $101.5 \pm 2.9 \%$; Fe $100.9 \pm 2.9 \%$; K: $98 \pm$ 1.8\%; Mg: $102.2 \pm 2.7 \%$; Mn: $98 \pm 2.2 \%$; Na $99.5 \pm 1.8 \%$ and $\mathrm{V}: 101.2 \pm 2.8 \%$. Results were in very good agreement with certified values for the tested elements proving good accuracy of the method employed.
All chemicals used in sample treatment were ultra-pure grade $\left(\mathrm{HNO}_{3}, \mathrm{H}_{2} \mathrm{O}_{2} 30 \%\right.$, Merck, Suprapur, Darmstadt, Germany). Ultra-pure water (Milli-Q system, Millipore Corporation, U.S.A.) was used for all solutions. All glassware was cleaned prior to use by soaking in $10 \% \mathrm{v} / \mathrm{v}$ $\mathrm{HNO}_{3}$ for 24 hours before rinsing with Milli-Q water. The standard metal solutions were prepared from stock standard solutions of ultra-pure grade supplied by Merck (Darmstadt, Germany).

The laboratory precision for the whole analytical process was tested by measuring the Relative Standard Deviation (RSD \%) of ten replicates for each sample tested $(n=10)$. The obtained values for the analysed elements were always below $7 \%$ proving the good repeatability of the analytical method. For details about uncertainty, precision, accuracy and methods validation see refs [47-50].

\section{Statistical methods}

Duplicate honey samples were collected at each site. The normality of distributions of the 19 elements determined 
Table 4 Argentine honey samples description

\begin{tabular}{lll}
\hline Samples & Product & Geographical origin \\
\hline M1 & Eucalipto honey & Colón, Entre Ríos \\
M3 & Chilca honey & Sierras de Córdoba, Córdoba \\
M4 & Algarrobo honey & Aguirre, Santiago del Estero \\
M5 & Mistol honey & Aguirre, Santiago del Estero \\
M6 & Citric honey & Alberdi, Tucumàn \\
M7 & Multifloral honey (organic) & Cruz del eje, Córdoba \\
M8 & Multifloral honey (pasture) & Castelar, Province of Buenos Aires \\
M9 & Multifloral honey & Gualeguaychú, Entre Ríos \\
M10 & Multifloral honey & Concordia, Entre Ríos \\
M11 & Multifloral honey & Mar del Plata, Province of Buenos Aires \\
M12 & Multifloral honey & Berazategui, Province of Buenos Aires \\
M13 & Multifloral honey (creamed) & La Plata, Province of Buenos Aires \\
M14 & Multifloral honey (organic) & Central area, Province of Buenos Aires \\
M15 & Multifloral honey & Tandil, Province of Buenos Aires \\
M16 & Multifloral honey & Central area, Province of Buenos Aires \\
\hline
\end{tabular}

was tested by using Shapiro-Wilk test $[51,52]$. Then the homogeneity for the data of the dual collected samples was tested. The $\mathrm{t}$ Student test was applied for testing univariate paired comparisons when normal distribution was obtained and the non parametric Wilcoxon rank sum test was applied for the other elements with not normal distribution [53,54]. Results confirmed the data homogeneity (data not shown) and then we merge the data of duplicated samples.

Several approaches can be employed for data analysis in this kind of studies $[55,56]$. In this work we first applied the hierarchical cluster analysis [57-60] to the data set (16 samples; and 19 elements plus 3 physiological parameters) in order to classify the distribution of the honey samples according to their production areas. The optimal number of clusters was determined by using the hierarchical cut-clustering rule.

The hierarchical clustering by minimum (energy) E-distance method was performed. Dissimilarities are $\|x-y\|^{a}$ where the exponent is in the interval $(0,2)$. This function performs agglomerative hierarchical clustering. Initially, each of the $n$ singletons is a cluster. At each of $n-1$ steps, the procedure merges the pair of cluster with minimum E-distance. The E-distance between two cluster $C_{i}, C_{j}$ of size $n_{i}$ and $n_{i}$ is given by

$$
e\left(C_{i}, C_{j}\right)=\frac{n_{i} n_{j}}{n_{i}+n_{j}}\left[2 M_{i j}-M_{i i}-M_{j j}\right]
$$

where

$$
M_{i j}=\frac{1}{n_{i} n_{j}} \sum_{p: 1}^{n_{i}} \sum_{q: 1}^{n_{j}}\left\|X_{i p}-X_{j q}\right\|^{a}
$$

II . I denotes Euclidean norm, $X_{i p}$ denotes the $p$-th observation in the $\mathrm{i}$-th cluster.

Then, discriminant analysis (DA) on principal component analysis (PCA) factors [61] was conducted with the aim to discriminate the elements and parameters classified by cluster analysis (CA). The 13 factors extracted by PCA (i.e. $100 \%$ of information) were included in DA. The analysis' significance was tested by Monte Carlo test (non parametric version of the Pillai's test) based on 999 replicates [62].

DA and PCA are considered statistical tools capable to reveal structures in environmental data [55,63,64]. In particular, PCA is a statistic technique belonging to the so-called "unsupervised pattern recognition methods," useful for carrying out exploratory data analysis when there is no preliminary knowledge about the characteristics (i.e., distribution and structure) of the data to be analyzed [65]. DA is a statistic technique belonging to the so-called "supervised pattern recognition methods," useful for carrying out specific data analysis when a previous unsupervised pattern recognition method, such as PCA, has suggested a potential discrimination among the data. Mainly for this cause, DA is applied to PCA results [66].

Data analysis was performed using the software $\mathrm{R}$ version 2.15 .2 (2012-10-26) - "Trick or Treat" and the packages Energy, Ade4. 


\section{Competing interests}

The authors declare that they have no competing interests.

\section{Authors' contributions}

MEC conceived of the study and, together with FB, MGF and II participated in its design and drafted the manuscript. MEC, GM and LF coordinated the sampling protocols and the whole analytical procedures. MEC and MGF participated in the design and performed the statistical analysis. This project was based on the ideas and under the guidance and consultation of MEC, MGF, FB and II. All authors read and approved the final manuscript.

\section{Acknowledgements}

M.E. Conti wishes to thank Cecilia Gauna for her assistance in the sample collection and classification.

\section{Author details}

'Department of Management, University of Rome, Sapienza, Via del Castro Laurenziano 9, Rome 00161, Italy. ${ }^{2}$ Italian National Institute for Environmental Protection and Research, Viale V. Brancati 60, Rome 00166, Italy. ${ }^{3}$ Institute of Occupational Medicine, Università Cattolica del Sacro Cuore, Largo Francesco Vito 1, Rome 00168, Italy. ${ }^{4}$ Department of Experimental Medicine, University of Rome, Sapienza, Viale Regina Elena 324, Rome 00161, Italy.

Received: 3 April 2014 Accepted: 24 June 2014

Published: 2 July 2014

\section{References}

1. Council Directive of the European Union: Council Directive 2001/110/EC of 20 December 2001 relating to honey. Offic J Eur Communities 2002, L10:47-52.

2. Domínguez MA, Grünhut M, Pistonesi MF, Di Nezio MS, Centurión ME: Automatic flow-batch system for cold vapor atomic absorption spectroscopy determination of mercury in honey from Argentina using online sample treatment. J Agric Food Chem 2012, 60:4812-4817.

3. Finola-Mónica S, Lasagno-Mirta C, Marioli-Juan M: Microbiological and chemical characterization of honeys from central Argentina. Food Chem 2007, 100(4):1649-1653.

4. Conti ME, Stripeikis J, Campanella L, Cucina D, Tudino MB: Characterization of Italian honeys (Marche Region) on the basis of their mineral content and some typical quality parameters. Chem Cent J 2007, 1:14.

5. Bogdanov S, Jurendic T, Sieber R, Gallmann P: Honey for nutrition and health: a review. Am J Coll Nutr 2008, 27:677-689.

6. Greenwood D: Honey for superficial wounds and ulcers. Lancet 1993 341(8837):90-91.

7. Taormina PJ, Niemira BA, Beuchat LR: Inhibitory activity of honey against food borne pathogens as influenced by the presence of hydrogen peroxide and level of antioxidant power. Int J Food Microbiol 2001, 69:217-225.

8. Molan P: Why honey is effective as a medicine: 2 . The scientific explanation of its effects. Bee World 2001, 82:22-40.

9. Pohl P: Determination of metal content in honey by atomic absorption and emission spectrometries. Trend Anal Chem 2009, 28(1):117-128.

10. Alvarez-Suarez JM, Tulipani S, Romandini S, Bertoli E, Battino M: Contribution of honey in nutrition and human health:a review. J Nutr Metab 2010, 3:15-23.

11. Abu-Tarbousch HM, Al-Kahtani HA, El-Sarrage MS: Floral-type identification and quality evaluation of some honey types. Food Chem 1993, 46:13-17.

12. Perez-Arquillue C, Conchello P, Arino A, Juan T, Herresa A: Quality evaluation of Spanish rosemary (Rosomarinus officinalis) honey. Food Chem 1994, 51:207-210.

13. Louveaux J, Maurizio A, Vorwohl G: Methods of melissopalynology. Bee World 1978, 59:139-157.

14. Song $X-Y$, Yao Y-F, Yang W-D: Pollen Analysis of Natural Honeys from the Central Region of Shanxi, North China. PLoS Biol 2012, 7(11):e49545.

15. Molan PC: The limitations of the methods of identifying the floral source of honeys. Bee World 1998, 79:59-68.

16. Conti ME, Botrè F: Honeybees and their products as potential bioindicators of heavy metals contamination. Environ Mon Ass 2001, 69:267-282.

17. Latorre MJ, Peña R, Pita C, Botana A, García S, Herrero C: Chemometric classification of honeys according to their type. II. Metal content data. Food Chem 1999, 66:263-268.
18. Bogdanov S, Ruoff K, Persano Oddo L: Physico-chemical methods for the characterisation of unifloral honeys: a review. Apidologie 2004, 35:S4-S17.

19. Pohl P, Stecka H, Sergiel I, Jamroz P: Different Aspects of the Elemental Analysis of Honeyby Flame Atomic Absorption and Emission Spectrometry: A Review. Food Anal Methods 2012, 5:737-751.

20. Bogdanov S, Haldimann M, Luginbuhl W, Gallmann P: Minerals in honey: environmental, geographical and botanical aspects. J Apic Res Bee World 2007, 46:269-275.

21. Pohl P, Sergiel I, Stecka H: Determination and fractionation of metals in honey. Crit Rev Anal Chem 2009, 39:276-288.

22. Conti ME, Saccares S, Cubadda F, Cavallina R, Tenoglio CA, Ciprotti L: II miele nel Lazio: indagine sul contenuto in metalli in tracce e radionuclidi. Riv Sci Alim 1998, 2:107-119.

23. Terrab A, Recamales AF, Hernanz D, Heredia FJ: Characterisation of Spanish thyme honeys by their physicochemical characteristics and mineral contents. Food Chem 2004, 88:537-542.

24. Conti ME: Lazio region (central Italy) honeys: determination of mineral content and typical quality parameters. Food Contr 2000, 11:459-463.

25. Baroni MV, Arrua C, Nores ML, Fayé P, Diaz MDP, Chiabrando GA, Wunderlin DA: Composition of honey from Córdoba (Argentina): Assessment of North/South provenance by chemometrics. Food Chem 2009, 114:727-733.

26. Serrano S, Villarejo M, Espejo R, Jodral M: Chemical and physical parameters of Andalusian honey: Classification of Citrus and Eucalyptus honeys by discriminant analysis. Food Chem 2004, 87:619-625.

27. Lazarevic KB, Andric F, Trifkovic J, Tesik Z, Milojkovic-Opsenica D: Characterization of Serbian unifloral honeys according to their physicochemicalparameters. Food Chem 2012, 132:2060-2064.

28. Codex Alimentarius Commission: Revised Codex Standard for Honey Codex Stan 12-1981, Rev. 1 (1987), Rev. 2 (2001). Codex Standard 1981, 12:1-7.

29. Código Alimentario Argentino (CAA): Productos azucarados, Volume 10. De La Canal y Asociados S.R.L; 1997:782-785.

30. Silvano MF, Varela MS, Palacio MA, Ruffinengo S, Yamul DK: Physicochemical parameters and sensory properties of honeys from Buenos Aires region. Food Chem 2014, 152:500-507.

31. Feas X, Pires J, Estevinho ML, Iglesias A, Araujo JPP: Palynological and physicochemical data characterisation of honeys produced in the EntreDouro e Minho region of Portugal. Int J Food Sci Tech 2010, 45:1255-1262.

32. Silva LR, Videira R, Monteiro AP, Valentao P, Andrade PB: Honey from Luso region (Portugal). Physicochemical characteristics and mineral content. Talanta 2009, 93:73-77.

33. Fernández-Torres R, Pérez-Bernal JL, Bello-López MÁ, Callejón-Mochón M, Jiménez-Sánchez JC, Guiraúm-Pérez A: Mineral content and botanical origin of Spanish honeys. Talanta 2005, 65:686-691.

34. Pellerano RG, Unates MA, Cantarelli MA, Camina JM, Marchevsky EJ: Analysis of trace elements in multiflora Argentine honeys and their classification according to provenance. Food Chem 2012, 134:578-582.

35. Grembecka M, Szefer P: Evaluation of honeys and bee products quality based on their mineral composition using multivariate techniques. Environ Monit Assess 2013, 185:4033-4047.

36. Enrich C, Boeykens S, Caracciolo N, Custo G, Vázquez C: Honey characterization by total reflection X-ray fluorescence: evaluation of environmental quality and risk for the human health. X-Ray Spectrom 2007, 36:215-220.

37. Tuzen M, Silici S, Mendil D, Soylak M: Trace element levels in honeys from different regions of Turkey. Food Chem 2007, 103:325-330.

38. Chudzinska M, Baralkiewicz D: Estimation of honey authenticity by multielements characteristics using inductively coupled plasma-mass spectrometry (ICP-MS) combined with chemometrics. Food ChemToxicol 2010, 48:284-290

39. Vanhanen LP, Emmertz AB, Savage GP: Mineral analysis of mono-floral New Zealand honey. Food Chem 2011, 128:236-240.

40. Habib HM, Al Meqbali FT, Kamal H, Souka UD, Ibrahim WH: Physicochemical and biochemical properties of honeys from arid regions. Food Chem 2014, 153:35-43.

41. Bilandzic N, Dokic' M, Sedak M, Solomun Kolanovic' B, Varenina I, Koncurat A, Rudan N: Determination of trace elements in Croatian floral honey originating from different regions. Food Chem 2011, 128:1160-1164.

42. Bilandzic N, Gacic M, Đokic M, Sedak M, Sipusic Đl, Koncurat A, Gajger IT: Major and trace elements levels in multifloral and unifloral honeys in Croatia. J Food Comp Anal 2014, 33:132-138.

43. Almeida-Silva M, Canha N, Galinha C, Dung HM, Freitas MC, Sitoe T: Trace elements in wild and orchard honeys. Appl Radiat Isotopes 2011, 69:1592-1595. 
44. Jakubowski M, Palczynski C: Beryllium in Handbook on the toxicology of metals. Edited by Nordberg GF, Fowler BA, Nordberg M, Friberg LT. Amsterdam: Elsevier; 2007:415-431.

45. Fermo P, Beretta G, Maffei Facino R, Gelmini F, Piazzalunga A: Ionic profile of honey as a potential indicator of botanical origin and global environmental pollution. Environ Pollut 2013, 178:173-181.

46. Association of Official Analytical Chemists (AOAC): Official methods of analysis (15 th edition). Arlington: Association of Official Analytical Chemists Inc; 1990

47. Pino A, Alimonti A, Botrè F, Minoia C, Bocca B, Conti ME: Determination of twenty five elements in lichens by sector field inductively coupled plasma mass spectrometry and microwave assisted acid digestion. Rapid Commun Mass Sp 2007, 21:1900-1906.

48. Bocca B, Conti ME, Pino A, Mattei D, Forte G, Alimonti A: Simple, fast, and low-contamination microwave-assisted digestion procedures for the determination of chemical elements in biological and environmental matrices by sector field ICP-MS. Int J Environ An Ch 2007, 87(15):1111-1123.

49. Conti ME, Muse JO, Mecozzi M: Uncertainty in environmental analysis: theory and laboratory studies. Int J Risk Assess Manag 2005, 5:311-335.

50. Chudzinska M, Debska A, Baralkiewicz D: Method validation for determination of 13 elements in honey samples by ICP-MS. Accred Qual Assur 2012, 17:65-73.

51. Royston P: An extension of Shapiro and Wilk's W test for normality to large samples. App/ Stat 1982, 31:115-24.

52. Royston P: Algorithm AS 181: The W test for Normality. App/ Stat 1982, 31:176-80.

53. Bauer DF: Constructing confidence sets using rank statistics. J Am Stat Assoc 1972, 67:687-90.

54. Hollander M, Wolfe DA: Nonparametric Statistical Methods. New York: John Wiley \& Sons; 1973:27-33. 68-75.

55. Conti ME, lacobucci M, Cecchetti G: A statistical approach applied to trace metal data from biomonitoring studies. Int J Environ Pollut 2005, 23(1):29-41.

56. Conti ME, lacobucci M, Cucina D, Mecozzi M: Multivariate statistical methods applied tobiomonitoring studies. Int J Environ Pollut 2007, 29(1-3):333-343.

57. Szekely GJ, Rizzo ML: Hierarchical Clustering via Joint Between-Within Distances: Extending Ward's Minimum Variance Method. J Classif 2005, 22(2):151-183.

58. Rizzo ML, Szekely GJ: DISCO Analysis: A Nonparametric Extension of Analysis of Variance. Ann App/ Stat 2010, 4(2):1034-1055.

59. Szekely GJ, Rizzo ML: Testing for Equal Distributions in High Dimension. Inter Stat 2004, 5.

60. Szekely GJ: E-statistics: Energy of Statistical Samples, Department of Mathematics and Statistics, Bowling Green State University. USA: Technical Report; 2000:03-05.

61. Thioulouse J, Chessel D, Doledec S, Olivier JM: ADE-4: a multivariate analysis and graphical display software. Stat Comput 1997, 7:75-83.

62. Chessel D, Dufour A, Thioulouse J: The ADE4 package. I. One-table methods. R News 2004, 4:5-10.

63. Conti ME, Mecozzi M: Multivariate approaches to biomonitoring studies. Biological monitoring: Theory and applications. Bioindicators and biomarkers for environmental quality and human exposure assessment. The sustainable world M. E Conti (Ed) 2008, 17:213-226.

64. Conti ME, Finoia MG, Bocca B, Mele G, Alimonti A, Pino A: Atmospheric background trace elements deposition in Tierra del Fuego region (Patagonia, Argentina), using transplanted Usnea barbata lichens. Environ Monit Assess 2012, 184:527-538.

65. Conti ME, Bocca B, lacobucci M, Finoia MG, Mecozzi M, Pino A, Alimonti A: Baseline trace metals in seagrass, algae and molluscs in a southern Tyrrhenian ecosystem (Linosa Island, Sicily). Arch Environ Con Tox 2010, 58:79-95.

66. Brereton RG: Chemometrics: application of mathematics and statistics to laboratory systems. Chichester, UK: Ellis Horwood; 1990.

doi:10.1186/1752-153X-8-44

Cite this article as: Conti et al:: Characterization of Argentine honeys on the basis of their mineral content and some typical quality parameters. Chemistry Central Journal 2014 8:44

Publish with ChemistryCentral and every
scientist can read your work free of charge
"Open access provides opportunities to our
colleagues in other parts of the globe, by allowing
anyone to view the content free of charge."
W. Jeffery Hurst, The Hershey Company.
- available free of charge to the entire scientific community
- peer reviewed and published immediately upon acceptance
- cited in PubMed and archived on PubMed Central
- yours - you keep the copyright
submit your manuscript here:
http://www.chemistrycentral.com/manuscript/

